\title{
PKM Musyawarah Guru Mata Pelajaran (MGMP) Kimia Kabupaten Donggala Dalam Penyusunan Dan Publikasi Karya Ilmiah
}

\author{
Sitti Rahmawati, Baharuddin Hamzah \\ Program Studi Pendidikan Kimia FKIP Universitas Tadulako \\ E-mail: sittirahmawati@yahoo.com
}

\begin{abstract}
Abstrak - Mitra dari kegiatan pengabdian ini adalah para guru Kimia yang tergabung pada Musyawarah Guru Mata Pelajaran (MGMP) kabupaten Donggala. Permasalahan yang dihadapi kelompok mitra antara lain Anggota Musyawarah Guru Mata Pelajaran Kimia (MGMP) masih mengalami kesulitan dalam: a) merancang pelaksanaan PTK dalam proses pembelajaran (cara mengidentifikasi masalah, memilih dan merumuskan topik dan judul penelitian tindakan kelas, b) menerapkan model-model pembelajaran dan media pembelajaran dalam pelaksanaan PTK dan cara pengambilan data yang tepat dan efisien, c) teknik penelusuran bacaan ilmiah terutama berupa jurnal untuk dijadikan acuan penulisan (penelusuran pustaka), d) menganalisis dan menginterpretasi data yang diperoleh selama melakukan penelitian, e) pembuatan instrumen penelitian khususnya PTK dan teknik penyajian datanya, f) teknik penulisan dan penyampaian naskah artikel ke jurnal ilmiah dan kurangnya nara sumber. Tujuan dari PKM ini adalah adalah melakukan kegiatan pendampingan dan pelatihan pada guru-guru kimia khususnya yang tergabung dalam MGMP Kimia Kabupaten Donggala dalam penyusunan laporan penelitian dan artikel yang memenuhi syarat untuk diterbitkan pada jurnal ilmiah yang didahului dengan pelatihan pengolahan dan analisis data hasil penelitian. Metode yang digunakan dalam kegiatan PKM ini adalah melakukan pelatihan dan workshop pelaksanaan PTK, pembuatan instrumen penelitian, pengolahan dan analisis data hasil penelitian. Selanjutnya akan mendampingi mitra dalam penyusunan laporan PTK dan publikasinya serta dapat mengolah data hasil penelitian PTK kedalam bentuk artikel karya ilmiah dan dipublikasikan di jurnal ber-ISSN ataupun pada seminar ilmiah tingkat nasional. Pelaksanaan workshop dan pelatihan penyusunan dan publikasi karya ilmiah sangat bermanfaat bagi MGMP Kimia kabupaten Donggala yang selama ini kesulitan memenuhi persyaratan kenaikan pangkat dalam bidang penulisan karya ilmiah. Pada penerapan praktik penyusunan artikel, tiga orang anggota MGMP kimia kabupaten Donggala, telah membuat laporan penelitian tindakan kelas, mengolah data dan menuliskan dalam artikel ilmiah, dan sementara di review untuk terbit di jurnal interaktif.
\end{abstract}

Kata Kunci: Penelitian Tindakan Kelas, Publikasi, Karya Ilmiah, Guru Kimia

Abstract - Partners of this service activity are Chemistry teachers who are members of the Donggala District Teacher Meeting (MGMP). The problems faced by the partner groups, including members of the Chemistry Subject Teacher Conference (MGMP), still experienced difficulties in: a) designing the implementation of CAR in the learning process (how to identify problems, select and formulate topics and titles for classroom action research, b) apply models learning and learning media in the implementation of CAR and how to collect data that is appropriate and efficient, c) scientific reading tracing techniques, especially in the form of journals to be used as a reference for writing (literature search), d) analyzing and interpreting data obtained during research, e) making instruments research, especially CAR and data presentation techniques, $f$ ) writing techniques and submitting article manuscripts to scientific journals and the lack of resource persons. The purpose of this PKM is to provide assistance and training for chemistry teachers, especially those who are members of the Donggala District Chemistry MGMP in preparing research reports and articles that meet the requirements for publication in scientific journals, preceded by training in processing and analyzing research data.. The method used in this PKM activity is conducting training and workshops on the implementation of CAR, making research instruments, processing and analyzing research data. Furthermore, they will assist partners in preparing the PTK report and its publication and can process the PTK research data into the form of scientific paper articles and published in ISSN journals or at national level scientific seminars. The implementation of workshops and training on the preparation and publication of scientific papers is very beneficial for the Chemistry MGMP of Donggala Regency which has had difficulty meeting the requirements for promotion in the field of writing scientific papers. In the application of the practice of writing articles, three members of the Chemistry MGMP of Donggala Regency, have made classroom action research reports, processed data and wrote in scientific articles, and temporarily reviewed them for publication in interactive journals.

Keywords: Classroom Action Research, Publications, Scientific Work, Chemistry Teachers 


\section{PENDAHULUAN}

Kriteria kenaikan pangkat bagi PNS guru tertuang dalam peraturan Menteri Negara Pendayagunaan Aparatur Negara dan Reformasi Birokrasi (PermenPANRB) No 16 Tahun 2009 Tanggal 10 November 2009. Dalam peraturan tersebut mulai Januari tahun 2013 bagi Guru PNS yang akan mengusulkan kenaikan pangkatnya harus memenuhi beberapa kriteria antara lain adalah kredit point yang harus didapat dalam pengembangan diri dan karya tulis [1].

Setiap guru harus mampu mengumpulkan angka kredit yang merupakan hasil karya dari program Pengembangan Keprofesian Berkelanjutan (PKB) berupa pengembangan diri (3 kredit), publikasi karya ilmiah, dan atau karya inovatif (4 kredit), sejak golongan III/b. Pengembangan profesi sebagaimana dijelaskan dalam peraturan pemerintah tersebut meliputi: 1). membuat karya tulis/karya ilmiah di bidang pendidikan, 2) menemukan teknologi di bidang pendidikan, 3). membuat alat pelajaran/alat peraga atau alat bimbingan atau media pembelajaran, 4). menciptakan karya tulis ilmiah, dan mengikuti kegiatan pengembangan kurikulum [1]. Konkritnya kegiatan- kegiatan tersebut harus dijabarkan dalam bentuk penulisan karya ilmiah baik melalui; penulisan makalah, modul dan bahan ajar, artikel, resensi, best praktis maupun melalui Penelitian Tindakan Kelas (PTK).

Kebijakan tentang pengembangan keprofesian berkelanjutan sebagai syarat naik pangkat diharapkan dapat meningkatkan profesionalisme guru, lebih termotivasi dalam meningkatkan kompetensi dan prestasinya, dan menjadi terbiasa dalam membuat karya tulis ilmiah. Kewajiban melakukan pengembangan profesi, khususnya karya ilmiah sebagai syarat kenaikan pangkat dan jabatan sudah diberlakukan pada guru golongan ruang IV/a yang akan naik golongan ruang IV/b ke atas. Khusus dari golongan ruang IV/a ke IV/b, guru wajib mengumpul angka kredit minimal 12 publikasi karya ilmiah. Jika belum mencapai angka kredit minimal 12, tidak boleh naik pangkat/jabatan.

Kenyataannya, mayoritas guru khususnya guru kimia yang berada di Kabupaten Donggala kesulitan mengumpul angka kredit dari aspek pengembangan profesi karena belum mampu melakukan penelitian dan penulisan karya tulis ilmiah. Hal ini terlihat dari DKG pada Tabel 2, dari 26 guru Kimia di Kabupaten Donggala, 1 orang golongan IV/a dan belum ada yang mencapai golongan ruang IV/b, yang tersebar di 17 sekolah. Musyawarah Guru Mata Pelajaran (MGMP) kimia kabupaten Donggala terdiri dari 17 sekolah negeri maupun swasta yaitu:
SMAN 1 Banawa, SMAN 1 Sindue, SMAN 1 Sirenja, SMAN 1 Balaesang, SMAN 2 Balaesang, SMAN 3 Balaesang, SMAN 1 Dampelas, SMAN 2 Dampelas, SMAN 1 Sojol, SMAN 2 Sojol, SMAN 1 Rio Pakava, SMAS Nasional Wani, SMAN 1 Banawa Tengah, SMAN 1 Sindue Tombusabora, SMAN 1 Sindue Tobata, SMAN 1 Balaesang Tanjung, SMAS YPTB Ketong. [3]. Dengan diberlakukannya Permenpan dan RB di atas, dapat dipastikan bahwa guruguru semakin kesulitan naik pangkat/golongan, bukan hanya golongan ruang IV/a melainkan mulai dari golongan ruang III/b.

MGMP yang diharapkan memfasilitasi para guru melakukan pengembangan profesi ternyata belum mampu menjawab kebutuhan guru karena selain kekurangan bahkan tidak ada tenaga profesional yang spesifik mendalami dan menguasai aspek penulisan karya tulis ilmiah. Berdasarkan wawancara dengan ketua MGMP kimia kabupaten Donggala, materi yang dibahas dalam MGMP masih terbatas pada perangkat pembelajaran (penyusunan RPP) dan alat evaluasi. Karena itu masih banyak permasalahanpermasalahan yang esensial yang dibutuhkan di sekolah-sekolah belum terungkap di MGMP yang tidak kalah pentingnya adalah pembuatan karya ilmiah (aspek pengembangan profesi guru) karena jika para guru tidak dapat mengumpulkan angka kredit dari pengembangan profesi berarti tidak dapat naik pangkat/jabatan dan golongan.

Berdasarkan kenyataan tersebut, tim pengabdi telah melaksanakan suatu kegiatan pengabdian, dengan judul "PKM Musyawarah Guru Mata Pelajaran (MGMP) Kimia Kabupaten Donggala dalam Penyusunan dan Publikasi Karya Ilmiah"

\section{METODE \\ Metode pendekatan}

Metode pendekatan yang telah dilakukan untuk menyelesaikan permasalahan mitra adalah: memberikan penjelasan aturan tentang peraturan pemerintah no 16 tahun 2009 mengenai kenaikan pangkat guru dan tentang pembuatan karya ilmiah secara umum khususnya penelitian tindakan kelas (PTK). Pemberian Pelatihan pembuatan laporan penelitian khususnya PTK, pengolahan data hasil penelitian, serta penulisan artikel hasil penelitian. Selanjutnya dilakukan pendampingan mengidentifikasi masalah, membuat instrument penelitian, melaksanakan PTK, menganalisa data serta penulisan hasil PTK dan artikel. 


\section{Pelaksanaan Kegiatan}

Program PKM MGMP kimia Kabupaten Donggala dilaksanakan di SMAN 1 Sindue Tobata. Kegiatan pengabdian yang dilaksanakan adalah:

1. Sosialisasi dengan pihak sekolah dan Dinas

2. Penjelasan tentang PermenPANRB no 16 tahun 2009, penentuan angka kredit dan kenaikan pangkat guru, sebagai informasi dan tambahan pengetahuan kepada Kelompok Mitra

3. Workshop dan pelatihan tentang:

a. Teknik Pembuatan PTK yang Baik

b. Perancangan pelaksanaan PTK dan penerapan model-model pembelajaran dalam pelaksanaan PTK

c. Teknik Analisa data dan interpretasi data

d. Teknik pengambilan/penyajian data dan pembuatan Instrumen penelitian

e. Teknik penelusuran pustaka

f. Teknik analisis data

g. Praktek Pembuatan Karya Tulis Ilmiah (PTK) :

- Mengidentifikasi, memilih judul

- Perencanaan Tindakan

- Pelaksanaan penelitian tindakan kelas

- Pembuatan Artikel hasil PTK

\section{HASIL PELAKSANAAN PKM}

Pelaksanaan workshop penulisan karya ilmiah

Pelaksanaan PKM diawali dengan sosialisasi kegiatan pengadian kepada kepala SMAN 1 Sindue Tobata dan MGMP Kimia Kabupaten Donggala. Kegiatan selanjutnya melaksanakan workshop dan pendampingan tentang penulisan karya ilmiah, khususnya PTK, untuk mengembangkan kompetensi profesionalisme guru, serta upaya untuk meningkatkan pengetahuan dan ketrampilan guru dalam membuat artikel yang dimuat dijurnal.

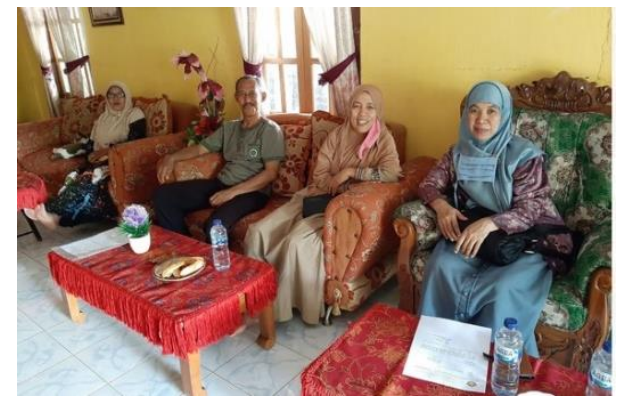

Gambar 1 Sosialisasi dengan Kepala SMAN 1 Sindue Tobata dan Ketua MGMP Kimia kabupaten Donggala

Pelatihan dilaksanakan di SMAN 1 Sindue Tobata, kepala sekolah sangat mendukung kegiatan pengabdian ini. Hal tersebut disampaikan pada saat pembukaan pelatihan karya tulis (Gambar 2). Dalam pelaksanaan pelatihan tersebut, peserta yang terlibat adalah anggota MGMP Kimia Kabupaten Donggala serta guru-guru bidang studi selain kimia yang bertugas di SMAN 1 Sindue Tobata.

Materi pada kegiatan workshop meliputi: Teknik Pembuatan Karya Ilmiah yang Baik, Teknik Analisa data dan interpretasi data, Teknik pengambilan/penyajian data dan pembuatan Instrumen penelitian, Teknik penelusuran pustaka, dan Teknik penulisan artikel pada jurnal ilmiah (Gambar 3a-d).

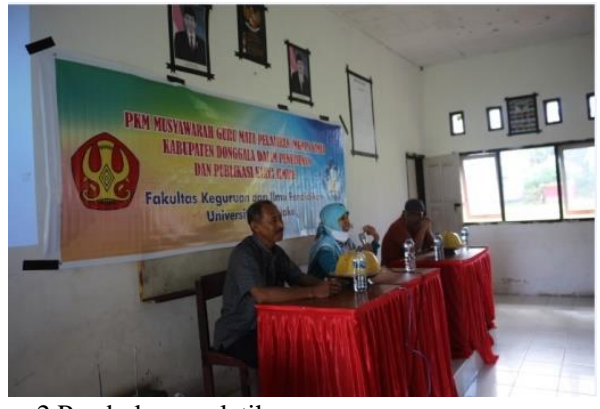

Gambar 2 Pembukaan pelatihan

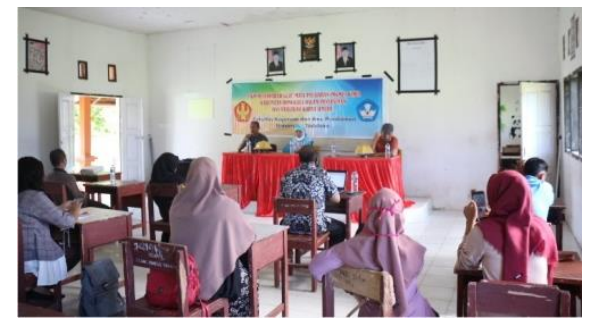

$\mathrm{a}$

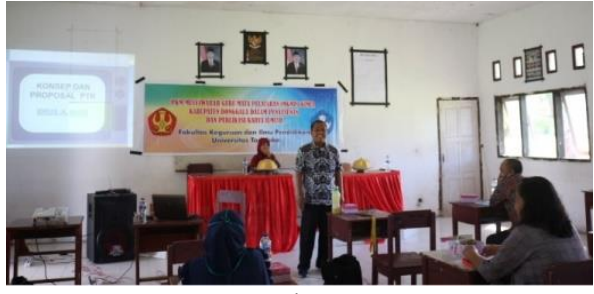

b
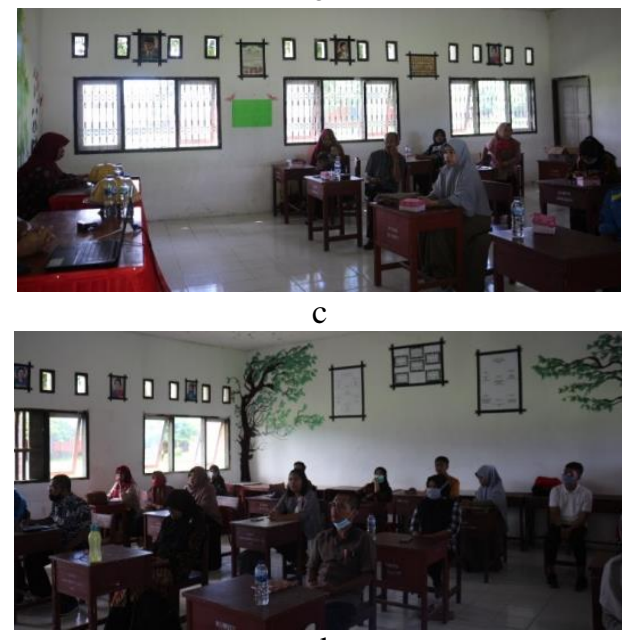

d

Gambar 3. Pelaksanaan pelatihan pembuatan karya tulis ilmiah 


\section{Kerja Praktek Pembuatan Karya Tulis Ilmiah}

Praktek pembuatan karya tulis ilmiah (PTK), dilaksanakan setelah guru-guru yang tergabung dalam MGMP Kimia selesai menerima materi. Pada tahap ini peserta dibagi menjadi 6 kelompok dengan masing-masing kelompok terdiri dari 5 orang yang akan didampingi oleh tim pelaksana PKM dan tenaga lapangan.

Kegiatan yang dilaksanakan pada kerja praktek adalah para peserta dibimbing/didampingi mulai dari mengidentifikasi masalah, membuat judul dan selanjutnya secara sistematika, pembuatan pendahuluan, kajian pustaka, metode penelitian, hasil dan pembahasan serta kesimpulan, dan selanjutnya dibimbing membuat artikel. Langkah-langkah tersebut sesuai dengan pedoman penulisan karya ilmiah dari berbagai sumber $[4,5,6,7]$

Semua kegiatan tersebut dilakukan secara bertahap, dimulai dari mengidentifikasi masalah yang ada di kelas yang diampu masing-masing guru, selanjutnya dari masalah tersebut, guru-guru diarahkan bagaimana langkah penyelesaiannya dan bagaimana membuat intrumen yang akan digunakan. Setelah peserta tersebut menemukan langkah penyelesaiannya dan instrumennya sudah siap digunakan, dilanjutkan dengan mempraktekkan hal tersebut di kelas. Pertemuan berikutnya didampingi untuk menganalisis data yang telah diperoleh, menuliskannya dalam bentuk artikel. Semua kegiatan pada praktek tersebut di damping oleh tim pelaksana PKM (Gambar 4).

Motivasi dan keingintahuan peserta MGMP Kimia yang tinggi untuk dapat meningkatkan profesionalisme khususnya pada bidang penulisan karya ilmiah, pengembangan media dan modelmodel pembelajaran yang bisa dilakukan dalam proses pembelajaran dalam mengatasi permasalahan pembelajaran di kelas sehingga dapat dikembangkan menjadi penelitian tindakan kelas (PTK) merupakan suatu factor positif yang sangat mendukung terlaksananya kegiatan pengabdian ini. Motivasi yang tinggi tersebut juga mendukung tercapainya luaran yang direncanakan, minimal 3 peserta dapat mempublish hasil PTK nya di jurnal berISSN.

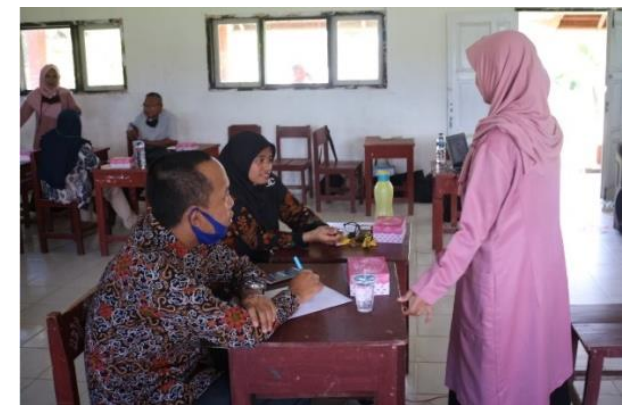

a

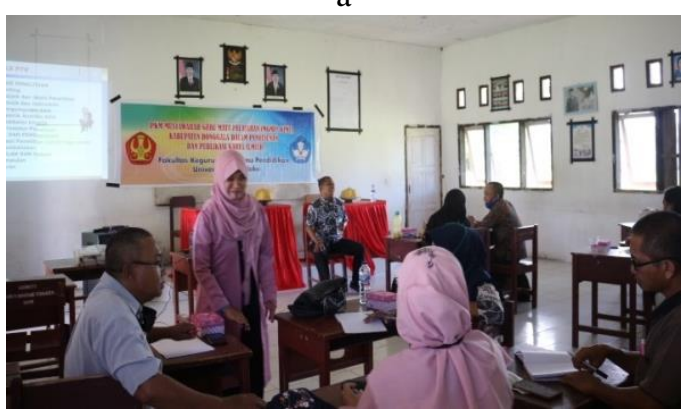

b

Gambar 4. Praktek pembuatan karya tulis ilmiah didampingi Tim PKM

Luaran yang telah dicapai, adalah artikel hasil PTK dari mitra MGMP Kimia kabupaten Donggala terdiri dari 6 judul artikel dan telah dikirim ke jurnal Interaktif (ber-ISSN), sementara dalam proses review untuk diterbitkan (Gambar 5). Manfaat yang diperoleh oleh mitra MGMP Kimia kabupaten Donggala, mampu meningkatkan profesionalismenya dan menjadi terbiasa dalam membuat karya tulis ilmiah. Kewajiban melakukan pengembangan profesi, khususnya karya ilmiah sebagai syarat kenaikan pangkat dan jabatan dapat dipenuhi. Para guru lebih mudah memenuhi salah satu kriteria kenaikan pangkat aspek pengembangan profesi guru yaitu pembuatan karya ilmiah. 


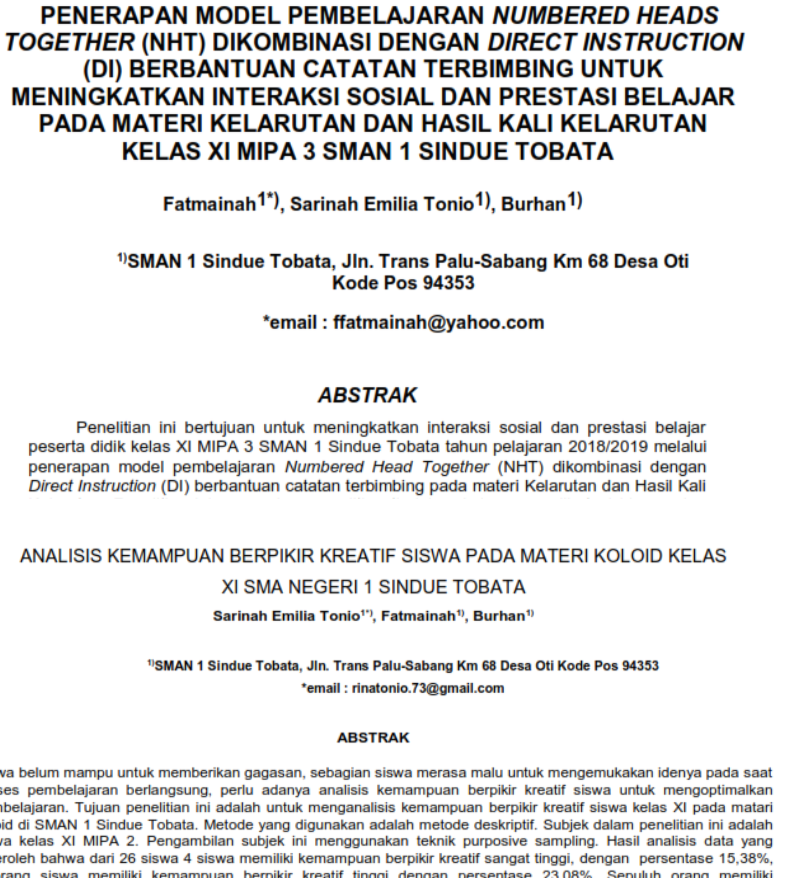

Gambar 5. Artikel Peserta kegiatan workshop dan pelatihan pembuatan karya ilmiah

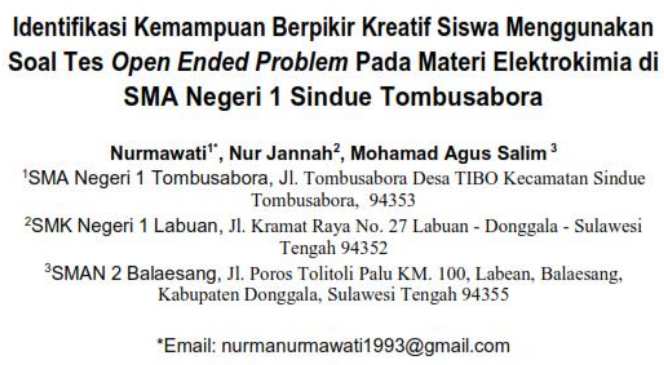

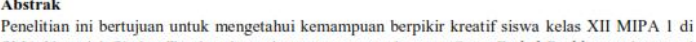
SMA Negeri 1 Sindue Tombusabora dengan menggunakan tes Open Ended Problem pada materi elektrokimia: mengetahui tanggapan guru terhadap soal Open Ended Problem yang diujikan dan

PENINGKATAN HASIL BELAJAR SISWA MELALUI PENGGUNAAN MEDIA VISUAL DENGAN PENDEKATAN KONTRUKTIVISME DALAM PEMBELAJARAN KIMIA PADA KELAS X MIA 3 SMA NEGERI 1 SIRENJA

Ahyadin ${ }^{1}$, Fatnur', Marwiah' -Sibado, No. 68, Tompe, Kecamatan Sirenja, Kode Pos. 94354 "Email: ahyadin.spd@gmail.com Abstrak

Permasalahan utama pada penelitian ini adalah rendahnya hasil belajar kimia siswa kelas $\mathrm{X}$ MIA SMAN 1 Sirenja khususnya materi stuktur atom dan sistem periodik. Ada beberapa faktor yang menyebabkan rendahnya hasil belajar siswa, diantaranya adalah materi pembelajaran bersifat abstrak serta pendekatan pembelajaran yang selama ini digunakan berpusat pada guru. Untuk meningkatkan hasi belajar siswa, maka peneliti menerapkan pembelajaran melalui penggunaan media visual denga pendekatan pembelajaran konstruktivisme. Aspek yang diamati dalam penelitian ini adalah aktivitas gur

\section{KESIMPULAN}

Kegiatan pengabdian pada mitra MGMP Kimia Kabupaten Donggala telah terlaksana dengan baik. Hal tersebut tergambar dengan adanya enam artikel yang telah peserta buat dari hasil pelatihan dan pendampingan PKM ini. Artikel tersebut telah dikirim ke jurnal Interaktif, sementara dalam proses review untuk diterbitkan di jurnal interaktif. Hal tersebut menggambarkan bahwa mitra MGMP Kimia kabupaten Donggala, mampu meningkatkan profesionalismenya dan menjadi terbiasa dalam membuat karya tulis ilmiah. Kewajiban melakukan pengembangan profesi, khususnya karya ilmiah sebagai syarat kenaikan pangkat dan jabatan dapat dipenuhi.

\section{UCAPAN TERIMA KASIH}

Para penulis berterima kasih atas dukungan finansial dari DRPM Kemenristek DIKTI Nomor: 091/SP2H/PPM/PRPM/2020,16 Maret 2020.

\section{DAFTAR PUSTAKA}

[1] Depdiknas, 2009. Peraturan Menteri Pendayagunaan Aparatur Negara dan Reformasi Birokrasi. Jakarta.
[2] Depdiknas, 2001. Pedoman Perhitungan Angka Kredit. Jakarta

[3] Dinas Pendidikan dan Kebudayaan Kabupaten Donggala, 2018. Daftar Keadaan Guru (DKG) Kabupaten Donggala.

[4] Saukah, A. dkk. 2001. Pedoman Penulisan Karya Ilmiah (Ed. $\left.4^{\text {th }}\right)$. Malang: Universitas Negeri Malang.

[5] Sekolah Pascasarjana (SPS) ITB, 2008. Pedoman Format Penulisan Tesis Magister. Institut Teknologi Bandung: Bandung. (http://www.sps.itb.ac.id)

[6] Usman H.B., dkk. 2001. Buku Pedoman Penulisan Karya Ilmiah Mahasiswa Jurusan Pendidikan MIPA. Palu.

[7] Aziz, A. 2003. Menyusun Rancangan Penelitian Kualitatif. Dalam Bungin, B.(Ed), Metodologi Penelitian Kualitatif (hlm. 37-49). Jakarta: PT Raja Grafindo Persada. 
Jati Emas (Jurnal Aplikasi Teknik dan Pengabdian Masyarakat)

Vol. 4 No. 2 Oktober 2020 - e. ISSN: 2550-0821 